\title{
Impact of T-lymphocyte populations on long-term cardiovascular prognosis in patients with coronary artery disease
}

\author{
O. Ivanova ${ }^{1}, \underline{\text { A. Lebedeva }}{ }^{1}$, J.C. Grivel ${ }^{2}$, A. Shpektor ${ }^{1}$, E. Vasilieva ${ }^{1}$, L. Margolis ${ }^{3}$
}

${ }^{1}$ Moscow State Univercity of Medicine and Dentistry, Laboratory of Atherothrombosis, Moscow, Russia

2Sidra Medical and Research Center, Deep Phenotyping Core, Doha, Qatar

${ }^{3}$ National Institute of Child Health and Human Development, Section of Intracellular Interactions, Washington, USA

\section{Background and Aims:}

It is assumed that activation of the immune system in coronary artery disease (CAD) leads to atherosclerotic plaque destabilization and to development of acute coronary syndrome (ACS). Thus, previous studies showed elevated levels of different T-lymphocyte subsets in the blood of patients with ACS. Moreover, in a univariant analysis, it was shown that cardiovascular (CV) event-free survival decreased in patients with higher percentages of late-differentiated $\mathrm{CD} 4^{+} \mathrm{T}$ cells. The aim of this work was to analyze the effect of different T-cell populations on prognosis in patients with CAD independently from the traditional CV risk factors.

\section{Methods:}

We analyzed T-lymphocyte populations in the blood of 70 patients with CAD (50 patients with ACS and 20 patients with stable CAD, mean age $63,7 \pm 11,3$ years) during the first $24 \mathrm{~h}$ after admission using multiparametric flow cytometry (Figure 1). We conducted a 3-year follow-up for CV events (Table 1) and performed a logistic regression analysis of risk factors for survival including the traditional $\mathrm{CV}$ risk factors and the percentages of $\mathrm{T}$-cell subpopulations.

Table 1. Patients' characteristics

\begin{tabular}{|l|c|}
\hline \multicolumn{2}{|c|}{ Basic characteristics } \\
\hline Age, years & $63.7 \pm 11.3$ \\
\hline Gender, m/f & $46 / 24$ \\
\hline Hyperlipidemia & $75.7 \%(53)$ \\
\hline Hypertension & $78.6 \%(55)$ \\
\hline Diabetes & $14.3 \%(10)$ \\
\hline Smoking & $41.4 \%(29)$ \\
\hline Obesity & $8.6 \%(6)$ \\
\hline $\begin{array}{l}\text { Prior cardiovascular } \\
\text { disease (TIA/ stroke, } \\
\text { ACS/angina pectoris) }\end{array}$ & $68.6 \%(48)$ \\
\hline \multicolumn{2}{|c|}{ Clinical endpoints at 3 years } \\
\hline TIA/Stroke & $4.8 \%(2)$ \\
\hline ACS hospitalizations & $2.4 \%(1)$ \\
\hline Repeated PCI & $23.8 \%(10)$ \\
\hline $\begin{array}{l}\text { Life-threating } \\
\text { arrhythmia }\end{array}$ & $4.8 \%(2)$ \\
\hline Angina pectoris & $14.3 \%(6)$ \\
\hline CV mortality & $26.2 \%(11)$ \\
\hline Combined endpoint & $71.4 \%(30)$ \\
\hline
\end{tabular}

Figure 1. Gating strategy for flow cytometry

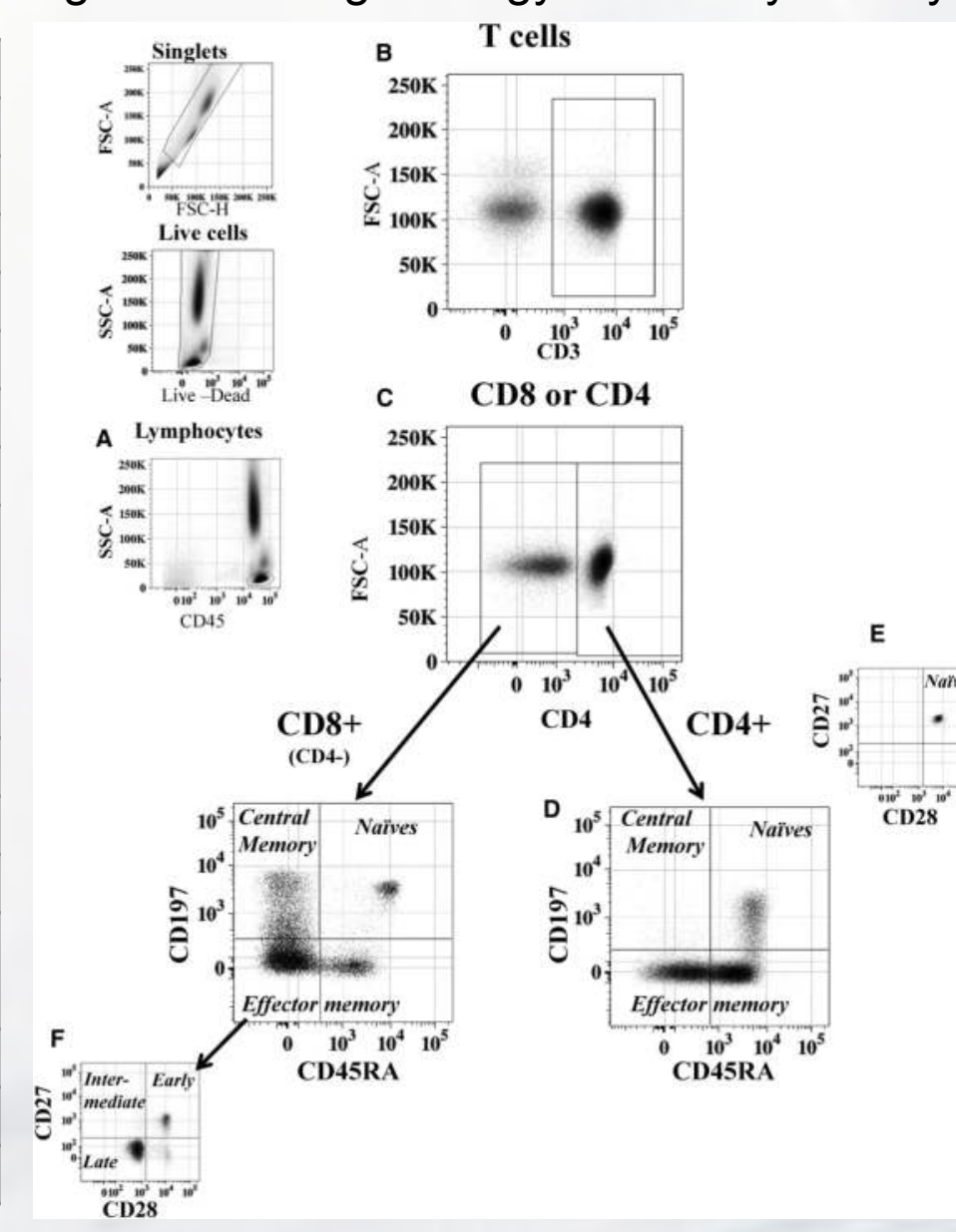

\section{Results:}

We found in the univariate analysis of all T-cell subpopulations that the risk of recurrent $\mathrm{CV}$ events during 3 years decreased with the increase in percentages of $\mathrm{CD}^{+}$and $\mathrm{CD}^{+}$naive $\mathrm{T}$ cells $(\mathrm{OR}[95 \% \mathrm{Cl}$ ] respectively, 0.93 [0.87-1.00] $p=0.041 ; 0.92$ [0.85-0.98], $p=0.015)$. At the same time 3-year CV risk increased 1.09 times with $1 \%$ rise in $\mathrm{CD}^{+}{ }^{+}$intermediate-differentiated effector memory $\mathrm{T}$ cells (Tem ID) $(95 \% \mathrm{Cl}=1.01-1.18, \mathrm{p}=0.032)$ (Figure $2 \& 3)$. However, in the multivariate analysis the other independent significant risk factors of $\mathrm{CV}$ events were patients' age and CV events prior to the admission (OR [95\% Cl] respectively, 1.10 [1.02-1.17], $p=0.011 ; 4.64$ [1.11-19.44], $p=0.036$ ) (Figure 4). Moreover, percentages of $\mathrm{CD} 4^{+}$and $\mathrm{CD}^{+}$naive $\mathrm{T}$ cells (but not of $\mathrm{CD} 4^{+} \mathrm{Tem}$ cells) were lower in patients with prior CV events (Figure 5) and negatively correlated with patients' age (Figure 6a \& b). Therefore, when analyzed in the multiple regression model, only patient's age, prior $\mathrm{CV}$ events and percentages of $\mathrm{CD}^{+}$effector memory $\mathrm{T}$ cells were independent risk factors worsening 3-year $\mathrm{CV}$ prognosis in CAD patients (Figure 7 ).
Figure 2. Odds of $\mathrm{CV}$ events within 3 years for $\mathrm{CD} 4^{+} \mathrm{T}$ cells.

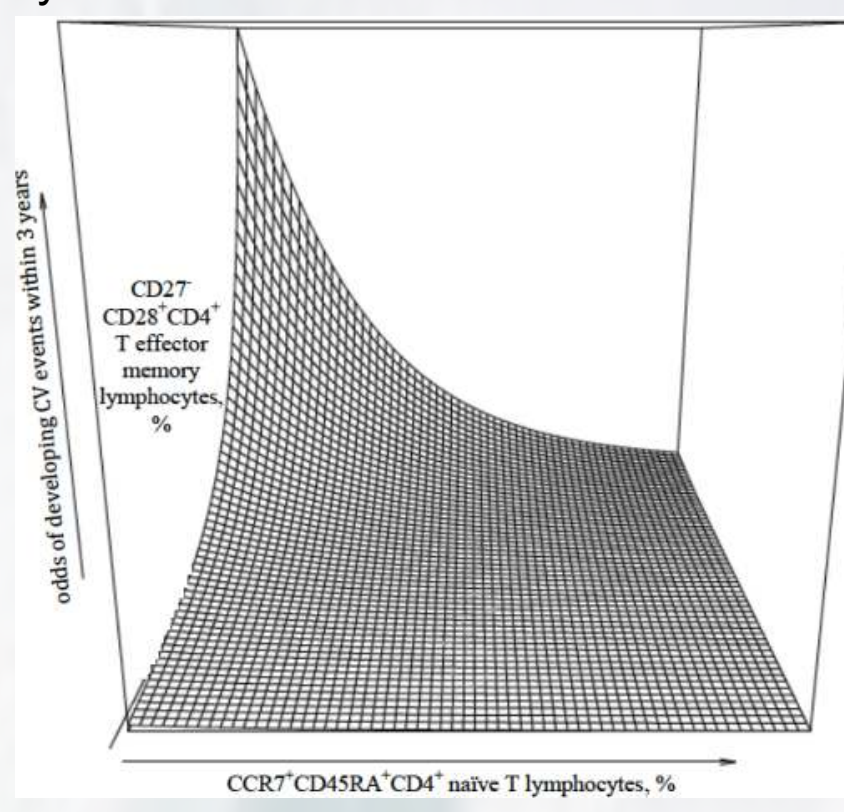

Figure 4. Odds of $\mathrm{CV}$ events within 3 years for age and prior CV events

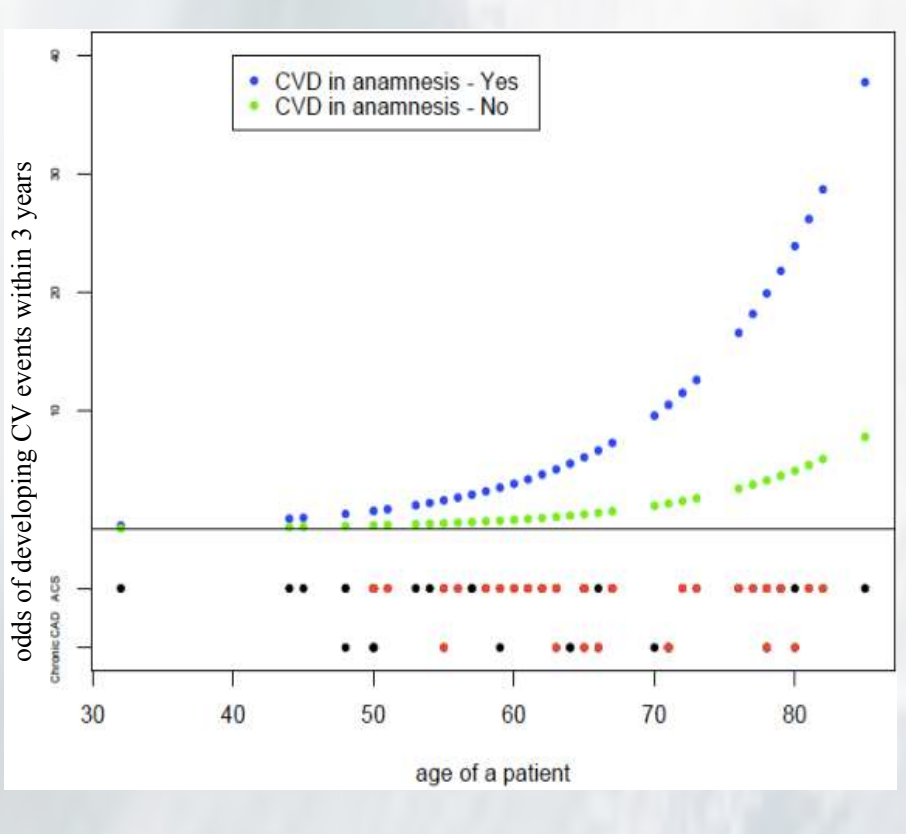

Figure 5. $\mathrm{CD} 4^{+}$and $\mathrm{CD} 8^{+}$naive $\mathrm{T}$ cells in patients with/without prior $\mathrm{CV}$ events

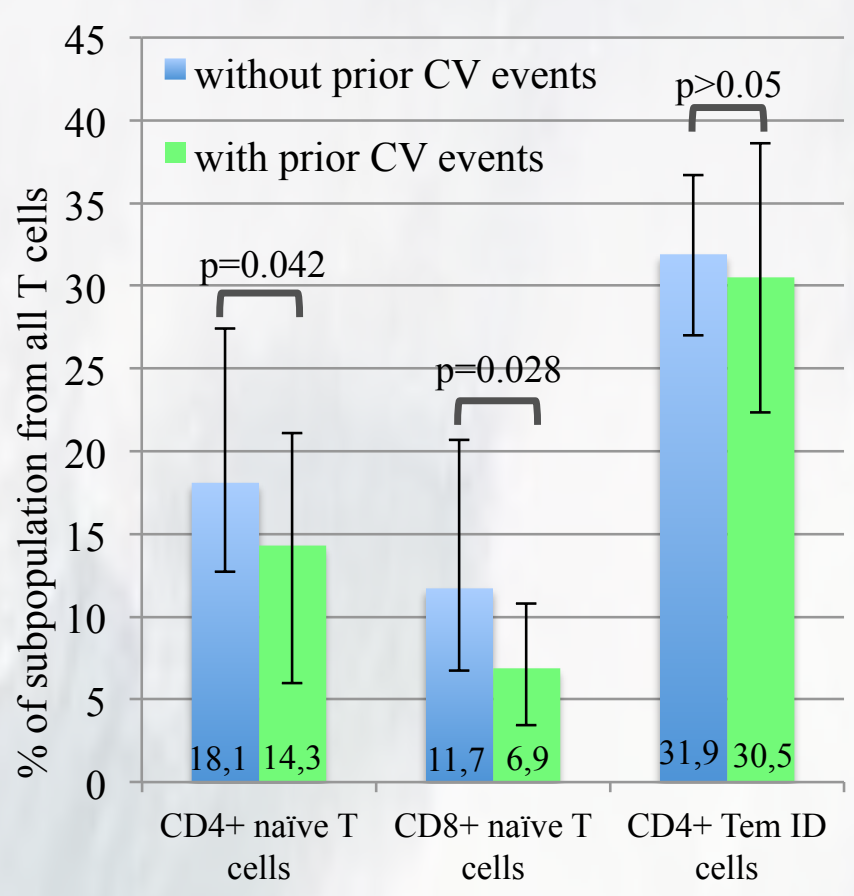

Figure 6. Correlation of (a) naïve $\mathrm{CD} 4^{+} \mathrm{T}$ cells and (b) naïve $\mathrm{CD} 8^{+} \mathrm{T}$ cells with age

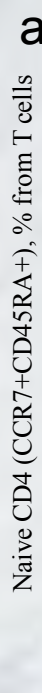
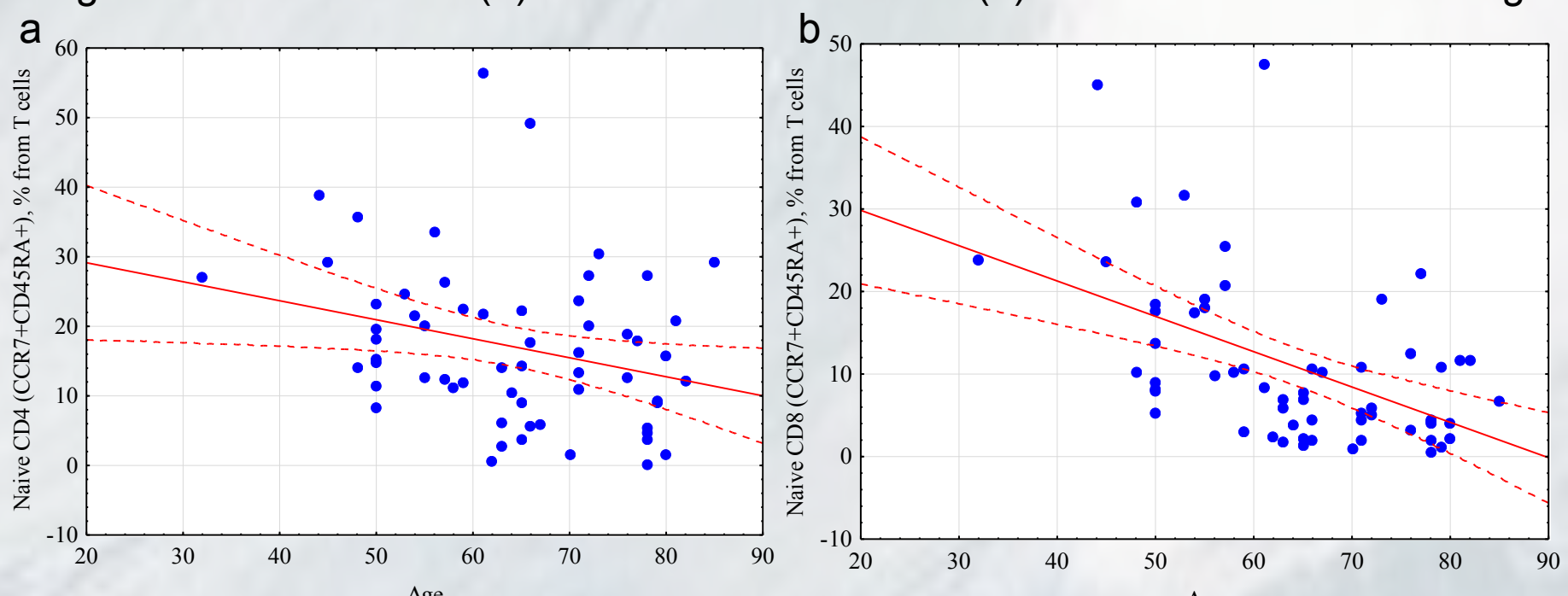

Figure 7. Multiple regression model for independent risk factors of $\mathrm{CV}$ events within $3-$

\begin{tabular}{|c|c|c|c|}
\hline Factor & $\begin{array}{l}\text { R } \\
\% \mathrm{Cl} \text { ) }\end{array}$ & $\begin{array}{c}\text { OR } \\
( \pm 95 \% \mathrm{Cl})\end{array}$ & $\mathbf{P}$ \\
\hline Age & $\infty$ & $1.11[1.03-1.21]$ & 0.012 \\
\hline$\%$ of CD4 Tem ID & $\infty$ & $1.13[1.02-1.25]$ & 0.023 \\
\hline Prior CVD & & $12.06[1.53-94.83]$ & 0.018 \\
\hline
\end{tabular}

\section{Conclusions:}

We showed that the risk of recurrent cardiovascular events during 3 years after the admission of CAD patients increased with the lower percentage of $\mathrm{CD} 4^{+}$and $\mathrm{CD} 8^{+}$naïve $\mathrm{T}$ cells and the higher percentage of $\mathrm{CD} 4^{+}$effector memory $\mathrm{T}$ cells. However, the amount of subpopulations of naive $T$ cells correlates negatively with patients' age. Therefore, only the differentiation of effector memory T cells in blood was found to be an independent risk factor for cardiovascular prognosis. 